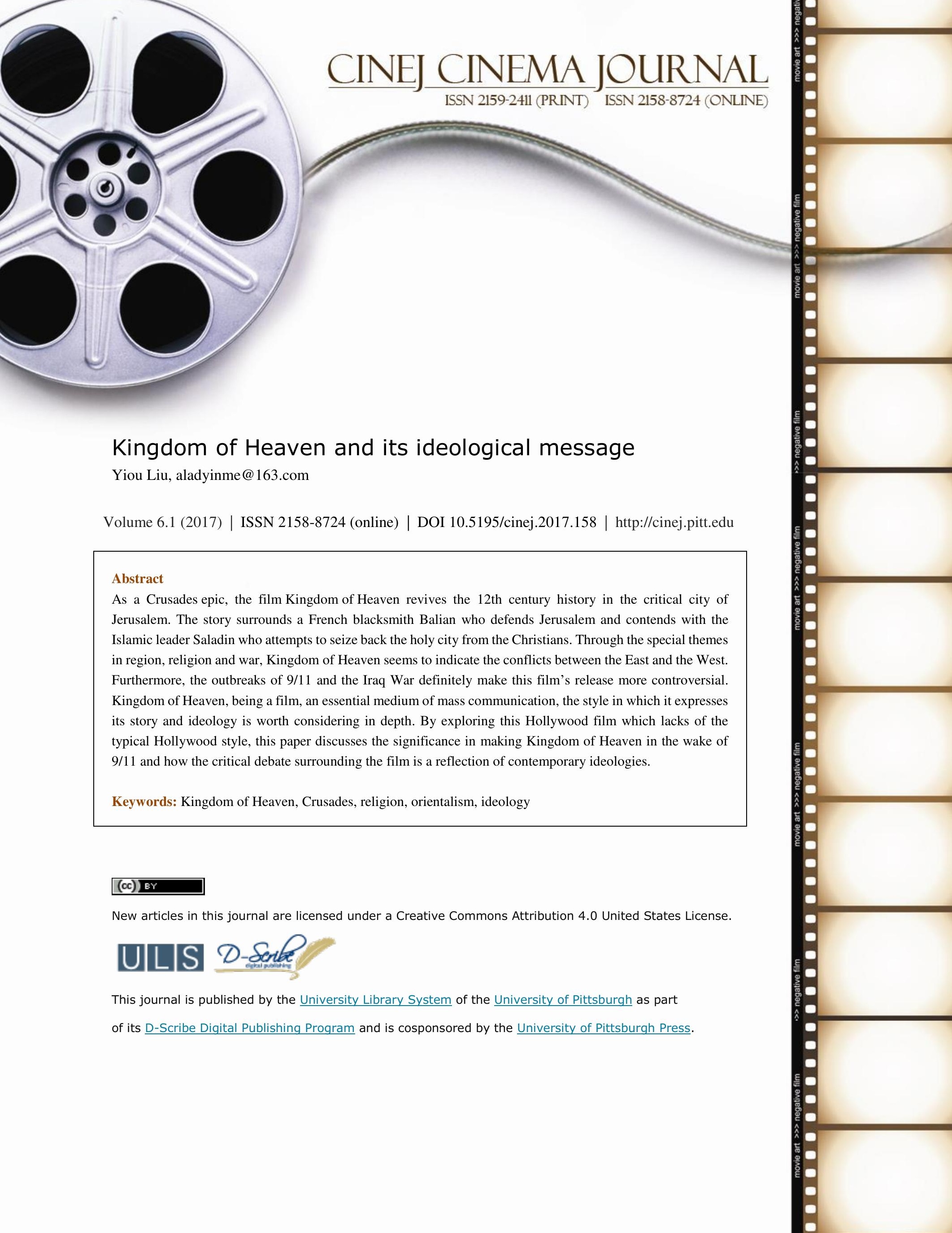




\section{Kingdom of Heaven and its ideological message Yiou Liu}

Kingdom of Heaven is an epic action movie directed by English director Ridley Scott and was released in the year 2005. The film costs US\$150 million dollars, shot in Spain and Morocco and with the main characters starred by Hollywood star Orlando Bloom and numerous actors of West Asia. According to Diller's theory (cited in Justin, W., 1994), Kingdom of Heaven is a "high concept" movie. Because it has famous director and stars that face to international market, the storyline can be described by a few words. Furthermore, it connects with contemporary events. As Ridley Scott explained (Monroe, 2005), they pre-decided to make this movie before the Iraq War, but shortly after the Black Hawk Down made by him, 9/11 occurred. Due to the tension of bilateral relations and its sensitive topic, there was a possibility of Kingdom of Heaven being delayed indefinitely. However, after 9/11, Scott eventually announced that he would make this movie for due to its relevancy to the unfortunate event. As a consequence, the audiences across the globe have the opportunity to set their eyes on this film in 2005. Although the narrative of the film was still in a controversial debate at the time of its release, it did not draw large audiences as expected when it was put on the public screen. Nevertheless, the history represented by Kingdom of Heaven is significant in the contemporary circumstances. This essay will discuss the circumstances for making this film prior and post 9/11, and analyze the relationships between the film narrative and its theme related to the ideologies. It will use critical materials to demonstrate what the plot of the movie wants to reflect and how the director had organized these factors to attain his intent. In addition, this paper will also discuss the significance of making the movie after $9 / 11$ and the ideologies expressed by the film. 
The film is an epic which involves history, religion, culture, war and love story in a Hollywood style. The story is about the Crusaders who protect Jerusalem from the Muslim forces from 1095 to 1291. A French blacksmith, Balian, urged by his long-absent father, joins the Crusaders and journeys to the Holy land on the second Crusade. After all the hopes for peace are destroyed by the religious fanatics' series of provocations, the war breaks out between the Crusaders and Muslim leader Saladin. When the Crusaders are almost completely annihilated, Balian shoulders the responsibility of protecting the people of Jerusalem. Eventually, Balian and Saladin reach an agreement after two weeks of pitched battle. As a consequence, the Christians could leave Jerusalem safely. The film refers to the Crusades as not only the past for the European Christians but also for the Muslims in Middle East. As a dream, these Crusades not only affect the Western mindset all the time throughout history, it is even the pronoun of just struggle in the American politics. The making and release of this film is post $9 / 11$ and post American invasion of Iraq. "This time, the new crusade with strong religious overtones pits fundamentalist Christian America and its allies, against political Islam and the Islamist al Qaeda terrorist organization". Then President George Bush stated that "This crusade, this war on terrorism, is gonna take awhile" (Tremblay, R., 2009). These words arouse Muslim grievance, as it has just the opposite denotation: the Crusades means sin and misery in Muslim world. Therefore, hatred on both sides is further sharpened. The theme of Kingdom of Heaven is not a conventional historical story, but it has a close relationship with anti-terrorism war.

Maltby (1995: 392) points out that "for any society, the maintenance of its people's belief in its political and economic system and in its cultural values is a matter of primary importance." In addition, ideology, culture and society overlap and co-exist dependently with each other. In a natural process, ideology translates its beliefs into culture practices and makes them become 
convention. As a cultural context, films always help to "instill ideology by creating an illusion that what happens on the screen is a neutral recording of objective events, rather than a construct operating from a certain point of view" (Michael, R. \& Kellner, D., 1988: 1). Normally, Hollywood represents familiarity to audiences and ideology works easily through these seemingly complex storylines. For example, Casablanca and Mr Smith Goes to Washington are classic representations of how politics is instilled in Hollywood movies. Furthermore, studies of these kinds of movies often focus on the effects of ideology and how about the attitudes of audiences shift before and after viewing the movies. In such a context, it is not surprising that Kingdom of Heaven arouses a lot of discussions after it has been presented to the large global audiences.

As Said (1978) argued in Orientalism, West is the subject while East is the object. The Western learning about the Oriental is just the product of attempting to conquer Orient. "Orientalism as a Western style for dominating, restructuring, and having authority over the Orient" (Said, E., 1978: 3). The description of Orient has been distorted either in academic researches or in literary works. From the Western perspective, the Orient world is savage, ugly, weak, feminine and exotic. Conversely, it appears that the Western culture and society "gained in strength and identity by setting itself off against the Orient as a sort of surrogate and even underground self" (Said, E., 1978: 3). Said considered this concept as irrational and anomic. In fact, it is just to meet the need for colonial expansion that the West fabricated the myth of Western world being completely better than Orient.

Orientalism is also reflected in the domain of film. For example, Hollywood has produced a lot of movies about Vietnam War during Reagan period, such as Go Tell the Spartans (1978), Platoon (1986) and Full Metal Jacket (1987). However, in the above movies, the Vietnamese soldiers are rarely portrayed positively; they are either weird or only in the shadows. In a similar 
context, Arabs are always linked with terrorism on the screens of Hollywood. As Shaheen (2003) stated, the mythology of Hollywood films that dominates mainstream culture, lead audiences to believe the Arabs are evil and that is the stereotype set by these films. Particularly in this case, the Islam religion is treated unfairly. "Today's imagemakers regularly link the Islamic faith with male supremacy, holy war, and acts of terror, depicting Arab Muslims as hostile alien intruders, and as lecherous, oily sheikhs intent on using nuclear weapons" (Shaheen, J. G, 2003: 9). It does not mean that Arabs cannot be represented as a hateful role, but it is a fact that Arabs are always depicted as the evil characters in almost all the Hollywood films. It is also astonishing how the films have emphasized these negative characters, for example the cruel torture and devices in Muslim dungeon in the movie of Robin Hood, the crazy Arab leader in True Lies, and the Arab terrorists in The Siege. As such, to find a positive Arab character is like "trying to find an oasis in the desert" (Shaheen, J. G, 2003: 34).

From what have been discussed above, it is obvious that Hollywood has a serious prejudice against Arabs even before the 9/11 terrorist attack. However, Kingdom of Heaven has not vilified and demonized the Christian main enemy Saladin as what traditional Hollywood films had typically done before, despite it being filmed after the fateful period. In fact, before the release of the film, there were many voices against this movie. Some conservative Christians thought the depiction of this period in history has somehow distorted the fact in order to calm Muslim hatred. Some experts of this historical period denounced the director for portraying an innocent and politically correct Saladin and his Arab Muslim army. Other Americans considered the film to have demonized the Crusades while ennobled the Muslim. After all, it seems that Arab Muslim has the same meaning with terrorism. David Hilborn, the Head of Theology at the Evangelical Alliance pointed out that "current tensions between Islam and the West make the crusades an even 
more delicate subject than usual" (Hilborn, D., 2005). On one hand, allied forces stars the Iraq War post-9/11 likes a new Crusade, as the history and film repeat together. On the other hand, Muslim leader such as Osama Bin Laden and Sadaam Hussein admire Saladin and even compare themselves to this Muslim hero who ever recaptured Jerusalem from the Crusaders. Hence, in the mist of this kind of sensitive circumstance, the making of this film would get little support. Who is righteous and who is the final victor is more important than ever before (Hilborn, D., 2005).

Regardless of whatever religion, audiences will tend to have an expectation before going to the cinema to watch Kingdom of Heaven. The rivalry between Christians and Muslims will probably be the theme of this film. However, the conflict between the Crusaders and the Arab army is superficial, this can be simply be perceived from the valuable judgment of how the positive and negative characters are not divided by religion. Positive characters are rational and peace seeking characters that are tolerant of religions, such as Balian, King Baldwin, Saladin and Balian's father Godfrey. For instances, while explaining the reason for retreat, Saladin emphasized the need for the supply of water and the readiness for war are as crucial as God's will. Similarly to Saladin's, Balian also stresses on the importance of water when he stops the Crusaders from attacks. They have reasonable and valid intents for a battle, for protecting the people or for revenging and punishing the villains. Most importantly, both Baldwin and Saladin allow people of all faiths to come to Jerusalem to pray. On the contrary, negative characters are aggressive religious fanatics, such as Guy, Reynald and the Templars and their basis of their motivation for provoking conflict is "God wills it" which they aim to eliminate infidels.

After breaking the audiences' expectations, the movie presents another series of conflicts between secular authority and religious authority along with the narrative. Firstly, at the beginning of the film, Balian killed the inhumane priest in his hometown. Secondly, on the way of escape, 
Godfrey killed the local bishop to protect his son. Thirdly, when Balian arrived in Jerusalem, he saw Templar was executed for killing Arabs. And finally, towards the end, King Baldwin punished the leader of Templar, and Saladin did the same thing after Hattin. According to Hilborn (2005), secular authority represents the American values which are set in the film while religious authority represents the terrorism values. Therefore, a series of punishments to the negative characters implies that the terrorists undoubtedly destroy themselves in the struggle with America. As symbols of such information transfer to audience imperceptibly, and "contemporary audiences will associate with one faction and give sins to another" (Brosnan, B., 2005). It means that once audiences identify the positive and secular authority, they will associate them with America. However, Hilborn considers that the movie has repeatedly associated to the US ideology, such as before Godfrey's death he described Jerusalem to Balian as "a new world. There, at the end of the world, you are not what you were born, but what you have it in yourself to be." In fact, it is not the truth but the core of the American dream. Just as Jerusalem is not a new world but the destination of pilgrims for hundreds of years and all its masters of the city, the holy land, are from the aristocratic families.

In the film, Saladin had done the things that Balian wanted to do, like executing the leader of Templar and depriving Guy de Lusignan's of his reign. It is believed that these two characters represent two aspects of the American ideology: state power and human right respectively. When the film depicts Saladin for the first time, it is said that "he has 200,000 men in Damascus alone. He could win a war if he goes to war, and he's daily given cause for war." It is similar to today's American military strength and terrorists' provocation. Some commented that the spectacular scene of throwing Greek fire when Muslim army surrounds the Jerusalem does not resemble a campaign in $12^{\text {th }}$ century, but a reconstruction of the powerful attacks of America in Iraq War. 
Similarly, the swift victory of Saladin against the Crusade in Hattin implies the easiness of US army's invasion of Iraq. Subsequently Saddin's revenge for his sister's death also indicates American vengeance for 9/11. In addition, Balian is a hero with humanity. He loses his family and journeys to the holy land by invitation of his father. Finally, when he fulfills the responsibility of protecting people, he returns to his hometown with his lover. This can be viewed as a representation of an American soldier who is called upon to Iraq after losing his family in 9/11 and upon completing the task of protecting the American mission, he returns home in triumph. Although it is somewhat unconvincing, America declares that the purpose of dispatching army troops to Iraq (or Afghanistan???) is simply to protect the people, rather than plunder the colony (Tremblay, R., 2009). At the end of the movie, when Saladin's army regains Jerusalem, he promises all inhabitants that they can pass through to Christian land safely. In speaking so, he picks up the cross to demonstrate his tolerance and kindness towards the Christians. As for Balian, before the Crusaders surrender, he promotes all men as Jerusalem knights so as to realize a kingdom of heaven by bestowing equality. Therefore, both of them are victors. The history of Christian disastrous campaign finally becomes America own national pride and victory.

To sum up, Kingdom of Heaven hides the conflict of culture and religion while uses myth to interpret ideological confrontation. The myth of the movie is: to abate the confrontation based on religions in war on terror and successfully transfers the conflict between Christian and Islamic into the rational conflict between America and terrorists. This is exactly the significance of making this neutral movie in the wake of 9/11. As the screenwriter William Monahan stated, "this knight's (Balian) oath of 'right action' is far more compelling than any religious doctrine or political ideology-and far less corruptible" (Brosnan, B., 2005). "It would prefer to clear religion away altogether, the better to assert a new universal humanism" (Hilborn, D., 2005). What is more, as a 
product for a global film market, this movie inevitably faces the international viewers. Despite of whether Arab audiences identified the image of Saladin and how American audiences unsatisfied with the Crusade's failure, it is undeniable that Kingdom of Heaven is acknowledged to have represented the history and the contemporary ideology critically and equally.

In conclusion, Kingdom of Heaven is a "polished, epic movie-making, with a compelling story line, strong characters, superb battle scenes and often stunning photography" (Hilborn, D., 2005). The fateful event of $9 / 11$ and tense circumstances make it the particular carrier of contemporary culture, politics and religion. As one of the representations of culture, this film plays an important role in preaching and maintaining the ideology. However, in the process of instilling the ideology, Hollywood movies are still full of prejudice towards the Orient world. Although some scholars, such as Said, has criticized the ignorance of Orientalism which is distorted by the West, it is still hard to uncover a positive character about Oriental, especially Arab. Just as the essay has discussed above, post American invasion of Iraq (Afganistan???) after 9/11 event, the perception of Arab Muslims as terrorists remains unchanged. Hence, the circumstance is much more sensitive than usual. Notwithstanding that, Kingdom of Heaven filmed under this particular kind of circumstances has broken audiences' assumption and re-divides the two sides of conflict. Along with the film's narrative, it implies the relations between America and terrorists remains and secular authority will defeat religious authority. Finally, the film gives the victory to all the positive characters skillfully and represents the history of the Crusade objectively. Though some of the controversies about the film seem too acidulous, the analysis in this essay should make the film clearer for audience to understand. As for the way in how this film reflects history, current event, religion and ideology, it is worth studying further. 


\section{BIBLIOGRAPHY}

Justin, W. (1994) High Concept: Movies and Marketing in Hollywood. Austin: University of Texas,

Monroe, C. (2005) Kingdom of Heaven: a spiritual journey away from God and toward Humanism. Christian spotlight on entertainment. Last accessed: 16 May, 2010 http://www.christiananswers.net/spotlight/movies/2005/kingdomofheaven2005-interview.html

Tremblay, R. (2009) America's New Crusade: Imperial U.S. vs Political Islam. Global Research.ca: Centre for Research on Globalization. Last accessed: 16 May, 2010 http://www.globalresearch.ca/index.php?context=va\&aid=16645

Maltby, R. (1995) Hollywood Cinema: An Introduction. Oxford: Blackwell.

Michael, R. \& Kellner, D. (1988) Camera Politica: The Politics and Ideology of Contemporary Hollywood Film. Bloomington: Indiana University Press.

Said, E. (1978) Orientalism. London: Penguin Books.

Shaheen, J. G. (2003) Reel Bad Arabs: How Hollywood Vilifies a People. New York \& Northampton: Olive Branch Press.

Hilborn, D. (2005) Review of Kingdom of Heaven. Evangelical Alliance. Last accessed: 16 May, 2010 http://www.eauk.org/theology/filmreviews/

Brosnan, B. (2005) Kingdom of Heaven. The Wire. Last accessed: 16 May, 2010 http://www.wirenh.com/Film/Film_reviews/Kingdom_of_Heaven_20050511456.html

Said, E. (1993) Culture and Imperialism. London: Chatto and Windus.

Louis, G. (1999) Understanding Movies. London: Prentice-Hall. 